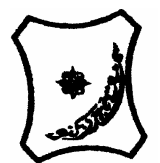

Bayero Journal of Pure and Applied Sciences, 5(2): $67-72$

Received: November 2012

Accepted: December 2012

ISSN $2006-6996$

\title{
PHYTOCHEMICAL COMPOSITION AND ACUTE TOXICITY EVALUATION OF AQUEOUS ROOT BARK EXTRACT OF SECURIDACA LONGIPEDUNCULATA (LINN)
}

\author{
*Auwal, S.M., Atiku, M.K., Wudil, A.M. and Sule, M.S. \\ Department of Biochemistry, Bayero University, Kano, Nigeria. \\ *Correspondence author: smayah01@hotmail.com +2348189587118
}

\begin{abstract}
This study was carried out to determine the phytochemical constituents and acute toxicity of the aqueous root bark extract of Securidaca longipedunculata Linn. The result of phytochemical screening revealed the presence of some secondary metabolites of pharmacological significance in the aqueous root bark extract including alkaloids, cardiac glycosides, flavonoids, saponins and tannins with saponins and tannins in larger quantities. The extract was found to have an $L D_{50}$ value of $771 \mathrm{mg} / \mathrm{kg}$ body weight when it was orally administered to rats, which indicate the root bark to be slightly toxic to the experimental animals. The toxicity of the root bark is attributed to some of the phytochemicals present in the plant.

Key words: Securidaca longipedunculata, root bark, aqueous extract, phytochemicals, acute toxicity.
\end{abstract}

\section{INTRODUCTION}

Phytochemicals are chemical compounds formed during the plants normal metabolic processes. These chemicals are often referred to as "secondary metabolities" of which there are several classes including alkaloids, flavonoids, coumarins, glycosides, gums, polysaccharides, phenols, tannins, terpenes and terpenoids (Harborne, 1973; Okwu, 2004). These can act as agents to prevent undesirable side effects of the main active substances or to assist in the assimilation of the main substances (Anonymous, 2007). Opium juice, for example from Papaver somniferum, contain other chemical compounds in addition to morphine and reports show that it gives fewer side effects than morphine administered on its own (Anonymous, 2007).

Phytochemicals are present in a variety of plants utilized as important components of both human and animal diets. These include fruits, seeds, herbs and vegetables (Okwu, 2005). Diets containing an abundance of fruits and vegetables are protective against a variety of diseases, particularly cardiovascular diseases (Okigbo et al., 2009). Herbs and spices are accessible sources for obtaining natural antioxidants (Okwu, 2004).

In contrast to synthetic pharmaceuticals based upon single chemicals, many medicinal and aromatic plants exert their beneficial effects through the additive or synergistic action of several chemical compounds acting at single or multiple target sites associated with a physiological process. These synergistic pharmacological effects can be beneficial by eliminating the problematic side effects associated with the predominance of a single xenobiotic compound in the body (Tyler, 1999). The synergistic interactions that underlie the effectiveness of a number of Phytomedicines has been extensively documented (Kaufman et al., 1999). Most of these phytochemical constituents are potent bioactive compounds found in medicinal plant parts which are precursors for the synthesis of useful drugs (Sofowora, 1993).

Toxicity is the degree to which a substance can damage an organism. Toxicity can refer to the effect on a whole organism, such as an animal, bacterium, or plant, as well as the effect on a substructure of the organism, such as a cell (cytotoxicity) or an organ (organotoxicity), such as the liver (hepatotoxicity). By extension, the word may be metaphorically used to describe toxic effects on larger and more complex groups, such as the family unit or society at large. A central concept of toxicology is that effects are dose-dependent and even water can lead to water intoxication when taken in large quantities/doses, whereas for even a very toxic substance such as snake venom there is a dose below which there is no detectable toxic effect (Cutler, 2010).

Toxicity can result from adverse cellular, biochemical, or macromolecular changes. Examples are: cell replacement, such as fibrosis, damage to an enzyme system, disruption of protein synthesis, production of reactive chemicals in cells and DNA damage. Some xenobiotics may also act indirectly by: modification of an essential biochemical function, interference with nutrition and alteration of a physiological mechanism (Cutler, 2010).

The toxicity of a substance depends on the following: form and innate chemical activity, dosage, especially dose-time relationship, exposure route, species, age, sex, ability to be absorbed, metabolism, distribution within the body, excretion and presence of other chemicals (Cutler, 2010). 
Toxicity can be measured by its effects on the target (organism, organ, tissue or cell). Because individuals typically have different levels of response to the same dose of a toxin, a population-level measure of toxicity is often used which relates the probabilities of an outcome for a given individual in a population. One such measure is the $L_{50}$ (Mark, 1999).

Toxic effects are generally categorized according to the site of the toxic effect. In some cases, the effect may occur at only one site. This site is referred to as the specific target organ. In other cases, toxic effects may occur at multiple sites. This is referred as systemic toxicity. Following are types of systemic toxicity: Acute Toxicity, Subchronic Toxicity, Chronic Toxicity Carcinogenicity, Developmental Toxicity and Genetic Toxicity (somatic cells) (Cutler, 2010).

By convention, many toxicology studies conducted in the early to mid 20th century were designed to identify the median lethal dose, or the dose required to kill 50 percent of the test population, " $L D_{50}$ " over a defined period of time. The most common $L_{50}$ test is the acute toxicity test, in which animals are given a single dose of chemical and the $\mathrm{LD}_{50}$ is determined over a 24-hour time period. Today, lethality studies are, conducted as a first step towards providing some insight into the relative potency of new chemicals (Mark, 1999).

Despite the widespread use of $S$. longepedunculata in all parts of Africa, not much has been reported in the literature about its mammalian toxicity. The few reports available are in connection with its trypanocidal and insect toxicity where it is used as a stored grain preservative (Atawodi et al., 2003; Belmain et al., 2001). When a herbal product is ingested, the body interacts with it in an attempt to get rid of any harmful toxins, especially if the body cannot convert the foreign substance into cellular components. These processes are commonly manifested by changes in enzyme levels and other cell components. The enzymes commonly involved include: aspartate aminotransferase (AST), alanine aminotransferase (ALT), creatine kinase (CK), amylase, and alkaline phosphatase. Also, components like urea and uric acid are vital diagnostic tools for toxicity (Wannang et al., 2005). In a previous study, it was found that aqueous extracts of the root bark of S. longepedunculata altered serum levels of these enzymes in rats; an indication of the potential toxicity of the plant which could as well result in tissue or organ damage. The vital organs that are commonly affected are heart, liver, pancreas, and kidney among others (Maxwell et al., 2007). The present research was designed to carryout phytochemical and acute toxicity evaluation of the aqueous root bark extract of S. longepedunculata.

\section{MATERIALS AND METHODS}

\section{Plant Identification and Collection}

The plant was collected in July, 2011 from Ningi Local government, Bauchi state, Nigeria. It was authenticated at the Botany unit, Biological Sciences Department, Faculty of Science, Bayero University Kano, Nigeria.

\section{Extraction of the Plant Materials}

The root bark was collected and carefully washed in clean water, and then dried at room temperature. They were subsequently pulverized to coarse powder and distilled water $\left(120 \mathrm{~cm}^{3}\right)$ was added to $16 \mathrm{~g}$ of the powdered root bark into a conical flask. The content of the flask was then shaken and the top was covered with aluminium foil and kept for 48hours at room temperature. The extract was then obtained by filteration using a whatman No1 filter paper and concentrated using vacuum evaporator.

\section{Identification of Chemical Constituents}

The phytochemical components of $S$. longepedunculata were determined using the methods of (Sofowora, 1993; Harbone, 1973; and Cuilei, 1994) with some minor modification.

\section{Test for Tannins}

$2.0 \mathrm{~cm}^{3}$ of the aqueous extract was diluted with distilled water in a test tube. $2-3$ drops of $5 \%$ ferric chloride solution was added. A green black or blue black colouration would indicate the presence of tannins.

\section{Test for flavonoids}

$0.5 \mathrm{~g}$ of the plant material was shaken with petroleum ether to remove the fatty materials (lipid layer). The defatted residue was dissolved in $20 \mathrm{~cm}^{3}$ of $80 \%$ ethanol and filtered. The filtrate was used for the following test:

$3 \mathrm{~cm}^{3}$ of the filtrate was mixed with $4 \mathrm{~cm}^{3}$ of $1 \%$ potassium hydroxide in a test tube and the colour was observed. A dark yellow colour indicated the presence of flavonoids.

\section{Test for Alkaloids}

To $10.0 \mathrm{~cm}^{3}$ of the aqueous extract in 2 separate test tubes, 2 -3 drops of Dragendoff's and Mayers reagents were separately added. An orange red precipitate/ turbidity with Dragendoff's or white precipitates with mayer's would denote the presence of alkaloids.

\section{Test for cardiac glycosides}

$5 \mathrm{~cm}^{3}$ of the aqueous extract was mixed with $2 \mathrm{~cm}^{3}$ of glacial acetic acid containing one drop of ferric chloride $(\mathrm{FeCl} 3)$ solution, followed by the addition of $1 \mathrm{~cm}^{3}$ concentrated sulphuric acid. Brown ring was formed at the interface which indicated the presence of deoxysugar of cardenoloides. A violet ring may appear beneath the brown ring, while in the acetic acid layer, a greenish ring may also form just gradually throughout the layer.

\section{Test for Saponins}

$0.5 \mathrm{~g}$ of the powder was taken in a test tube. $5.0 \mathrm{~cm}^{3}$ of water was added and vigorously shaken. A persistent froth that last for at least 15 minutes would indicate the presence of saponins.

\section{Quantitative Determination of Phytochemicals}

Phytochemicals were determined by the method of El - Olemyl et al. (1994). 


\section{Alkaloids}

The plant extract $\left(10 \mathrm{~cm}^{3}\right)$ was transferred into a $250 \mathrm{~cm}^{3}$ separatory funnel followed by dilute $\mathrm{H}_{2} \mathrm{SO}_{4}$ $\left(5 \mathrm{~cm}^{3}\right)$ and $\mathrm{H}_{2} \mathrm{O}\left(5 \mathrm{~cm}^{3}\right)$. The extract was shaken twice with $\mathrm{CHCl}_{3}\left(10 \mathrm{~cm}^{3}\right)$ and the combined $\mathrm{CHCl}_{3}$ extract was transferred to a second separatory funnel containing dilute $\mathrm{H}_{2} \mathrm{SO}_{4}\left(5 \mathrm{~cm}^{3}\right)$ and $\mathrm{H}_{2} \mathrm{O}\left(10 \mathrm{~cm}^{3}\right)$. The $\mathrm{CHCl}_{3}$ layer was discarded and the aqueous acidic layer was transferred to the contents of the first separating funnel. The extract was then made alkaline with ammonia and shaken for about half a minute. The alkaloids were extracted completely by successive portions of $\mathrm{CHCl}_{3}$ each of $20 \mathrm{~cm}^{3}$. (Complete extraction was tested using Mayer's reagent). The combined $\mathrm{CHCl}_{3}$ extract was shaken with $\mathrm{H}_{2} \mathrm{O}\left(5 \mathrm{~cm}^{3}\right)$. The extract was run through a plug of cotton wool, previously moisten with $\mathrm{CHCl}_{3}$ and covered with a little anhydrous sodium sulphate (for complete dehydration). The sodium sulphate was then washed with $\mathrm{CHCl}_{3}\left(5 \mathrm{~cm}^{3}\right)$. The combined $\mathrm{CHCl}_{3}$ extract was received in to a $250 \mathrm{~cm}^{3}$ dry conical flask. The $\mathrm{CHCl}_{3}$ was then completely distilled and neutral alcohol $\left(5 \mathrm{~cm}^{3}\right)$ was added and evaporated on to a boiling water bath. The residue was further heated on the boiling water bath for 10 minutes (to remove volatile bases). The residue was then dissolved in $\mathrm{CHCl}_{3}$ $\left(2 \mathrm{~cm}^{3}\right)$, and $\mathrm{N} / 50 \mathrm{H}_{2} \mathrm{SO}_{4}\left(20 \mathrm{~cm}^{3}\right)$ added and warmed on a water bath to remove the $\mathrm{CHCl}_{3}$ completely and cooled. The excess acid was then titrated with $\mathrm{N} / 50$ $\mathrm{NaOH}$ using methyl red as indicator till the first drop of $\mathrm{N} / 50 \mathrm{NaOH}$ caused color change from pink to yellow.

\section{Flavonoids}

The extract $\left(5 \mathrm{~cm}^{3}\right)$ was transferred in to a small flask and then hydrolysed by heating on a water bath with $10 \% \mathrm{H}_{2} \mathrm{SO}_{4}\left(10 \mathrm{~cm}^{3}\right)$ for 30 minutes. The original volume was reduced to half and the mixture was cooled on ice for 15 minutes where the flavonoids were precipitated. The cooled solution was then filtered and the residue was dissolved by pouring warm $95 \%$ ethanol $\left(50 \mathrm{~cm}^{3}\right)$ and further made to $100 \mathrm{~cm}^{3}$ with $95 \%$ ethanol. Aliquot $\left(5 \mathrm{~cm}^{3}\right)$ was pipetted into a $25 \mathrm{~cm}^{3}$ volumetric flask and diluted to volume with $50 \%$ ethanol. The absorbance of the resulting solution was measured at $370 \mathrm{~nm}$ against $50 \%$ ethanol blank. The flavonoid concentration was finally calculated using a reference curve of pure quercetin.

\section{Tannins}

Plant extract $\left(5 \mathrm{~cm}^{3}\right)$ was transferred to a stoppered conical flask and $0.1 \mathrm{~N}$ Iodine $\left(25 \mathrm{~cm}^{3}\right)$ and $10 \% 4 \%$ $\mathrm{NaOH}$ were added. This was mixed and kept in the dark for 15 minutes. The mixture was diluted with water and acidified with $4 \% \mathrm{H}_{2} \mathrm{SO}_{4}\left(10 \mathrm{~cm}^{3}\right)$. The mixture was then titrated with $0.1 \mathrm{~N}$ Sodium thiosulphate solution using starch solution as indicator. The volume $\left(\mathrm{cm}^{3}\right)$ of $0.1 \mathrm{~N}$ Iodine used corresponds to the sum of tannins and pseudotannins
[A]. Another $25 \mathrm{~cm}^{3}$ of the extract was mixed with gelatin solution $\left(15 \mathrm{~cm}^{3}\right)$ in a $100 \mathrm{~cm}^{3}$ measuring flask and complete to volume with water and filtered. To the filtrate $\left(20 \mathrm{~cm}^{3}\right), 0.1 \mathrm{~N}$ Iodine $\left(25 \mathrm{~cm}^{3}\right)$ and $4 \%$ $\mathrm{NaOH}\left(10 \mathrm{~cm}^{3}\right)$ were added. This was mixed and kept in the dark for 15 minutes. The mixture was then diluted with water $\left(10 \mathrm{~cm}^{3}\right)$ and acidified with $4 \%$ $\mathrm{H}_{2} \mathrm{SO}_{4}\left(10 \mathrm{~cm}^{3}\right)$ and then titrated with $0.1 \mathrm{~N}$ sodium thiosulphate using starch as indicator.The volume $\left(\mathrm{cm}^{3}\right)$ of $0.1 \mathrm{~N}$ Iodine used corresponds only to pseudotannins content [B]. Additionally, a blank experiment was carried out using distilled water.

\section{Saponins}

The plant extract $\left(50 \mathrm{~cm}^{3}\right)$ was placed in a $500 \mathrm{~cm}^{3}$ flask, $50 \%$ alcohol $\left(300 \mathrm{~cm}^{3}\right)$ was added and boiled under reflux for 30 minutes and filtered while hot through a coarse filter paper. Charcoal (2g) was added to the filtrate, boiled and filtered again while hot. The filtrate was cooled and an equal volume of acetone was added to completely precipitate the saponin. The precipitated saponin was collected by decantation and dissolved in small amount of boiling 95\% alcohol and filtered while hot. The filtrate was cooled to room temperature to separate the saponins in a relatively pure form. The clean supernatant fluid was decanted and the saponins suspended in alcohol $\left(20 \mathrm{~cm}^{3}\right)$ and filtered. The filter paper was then transferred to a dessicator containing anhydrous calcium chloride and left to dry and weighed.

\section{Cardiac glycosides}

Plant extract $\left(8 \mathrm{~cm}^{3}\right)$ was transferred to a $100 \mathrm{~cm}^{3}$ volumetric flask and $\mathrm{H}_{2} \mathrm{O}\left(60 \mathrm{~cm}^{3}\right)$ and $12.5 \%$ lead acetate $\left(8 \mathrm{~cm}^{3}\right)$ was added, mixed and filtered. The filtrate $\left(50 \mathrm{~cm}^{3}\right)$ was transferred into another $100 \mathrm{~cm}^{3}$ flask and $4.7 \% \quad \mathrm{Na}_{2} \mathrm{HPO}_{4}\left(8 \mathrm{~cm}^{3}\right)$ was added to precipitate excess $\mathrm{Pb}^{++}$ions. This was mixed and completed to volume with water. The mixture was filtered twice through some filter paper to remove excess lead phosphate. Purified filtrate $\left(10 \mathrm{~cm}^{3}\right)$ was transferred into clean Erlyn - meyer flask and treated with Baljet reagent $\left(10 \mathrm{~cm}^{3}\right)$. A blank titration was carried out using distilled water $\left(10 \mathrm{~cm}^{3}\right)$ and Baljet reagent $\left(10 \mathrm{~cm}^{3}\right)$. These were allowed to stand for one hour for complete color development. The color intensity was measured colimetrically at $495 \mathrm{~nm}$.

\section{Experimental Animals}

Fourteen male white albino rats (weighing 150 to $240 \mathrm{~g}$ ) were purchased from the Animal Room of the Biological Sciences Department, Bayero University, Kano. The rats were maintained under standard laboratory conditions and were allowed free access to both food and water throughout the period of the experiment.

The volume $\left(\mathrm{cm}^{3}\right)$ of the root bark aqueous extract given to each rat was determined by its weight and required dose as follows: 
Where concentration of the aqueous root bark extract $=100 \mathrm{mg} / \mathrm{cm}^{3}$

Percentage yield $(\mathrm{w} / \mathrm{w})$ of the extract $=$ amount produced $\times \underline{100}$

\section{Pharmacological Study}

\section{Acute Toxicity $\left(\mathrm{LD}_{50}\right)$ Testing}

Determination of acute toxicity $\left(\mathrm{LD}_{50}\right)$ was carried out using the method of Lorke (1983), Fourteen rats were used for acute toxicity testing for the determination of $\mathrm{LD}_{50}$ in two phases (Lorke, 1983). In the initial phase, the rats were divided into three groups of 3rats each. They were orally treated with 10,100 and $1000 \mathrm{mg} / \mathrm{kg}$ of the extract orally. The rats were observed for 24hours for any mortality. In the second phase, the rats were grouped into five of one rat each and orally treated with the extract at varying doses $(250,400$, 600,700 and $850 \mathrm{mg} / \mathrm{kg}$ ). The animals were observed for 24hours and the final $L D_{50}$ value was determined from the minimum concentration (full death) and maximum concentration (no death) of the dose.

\section{Statistical Analysis}

Comparison between groups was performed using

Student's paired t-test. Data are given as the mean \pm Standard deviation. Statistical significance was accepted at a level of $\mathrm{P} \square 0.05$.

\section{RESULTS}

The percentage yield $(\mathrm{w} / \mathrm{w})$ of the extract was found to be $62.5 \%$ at room temperature.

Identification of Chemical Constituents

Various phytochemical constituents from the aqueous root bark extract of $S$. longipedunculata Linn. were detected and the results were summarized in Table 1.

Quantitative Determination of Phytochemicals

The various phytochemicals identified from the aqueous root bark extract of $S$. longipedunculata Linn. were quantified and the results were summarized in Table 2.

\section{Pharmacological Study}

Acute Toxicity Study

The $L_{50}$ value in the rats was determined to be $771 \mathrm{mg} / \mathrm{kg}$ body weight intraperitoneally in Table 3 (a -b).

Table 1: Phytochemical constituents of the aqueous root bark extract of Securidaca logipedunculata

\begin{tabular}{lcc} 
& Constituents & Inference \\
\hline Alkaloids & + \\
Cardiac glycosides & + \\
Flavonoids & + \\
Saponins & + \\
Tannins & + \\
\hline Key : $+=$ present
\end{tabular}

Key : $+=$ present

Table 2: Quantitative estimation (mean) of some Phytochemical constituents from the aqueous root bark extract of Securidaca longipedunculata

\begin{tabular}{ll}
\hline Constituents & Quantity $\mathbf{( m g / k g )}$ \\
\hline Alkaloids & $14.69 \pm 0.13$ \\
Total tannins & $338.63 \pm 0.29$ \\
Pseudo tannins & $157.37 \pm 0.22$ \\
True tannins & $181.50 \pm 0.16$ \\
Flavonoids & $31.12 \pm 0.18$ \\
Saponins & $270.17 \pm 2.38$ \\
Cardiac glycosides & $24.37 \pm 0.14$ \\
\hline
\end{tabular}

Results are expressed as mean \pm SD

Table 3 (a-b): LD $_{50}$ (Oral) determination of the aqueous root bark extract of Securidaca longipedunculata

(a)

\begin{tabular}{|c|c|}
\hline Doses (mg/kg) & Result of first phase (mortality) $n=3$ \\
\hline 10 & $0 / 3$ \\
\hline 100 & $0 / 3$ \\
\hline 1000 & $3 / 3$ \\
\hline \multicolumn{2}{|l|}{ (b) } \\
\hline Doses (mg/kg) & Result of second phase (mortality) $n=3$ \\
\hline 250 & $0 / 1$ \\
\hline 400 & $0 / 1$ \\
\hline 600 & $0 / 1$ \\
\hline 700 & $0 / 1$ \\
\hline 850 & $1 / 1$ \\
\hline
\end{tabular}

$\mathrm{n}=$ number of rats per group 


$$
\begin{aligned}
& \mathbf{L D}_{\mathbf{5 0}}=\underset{700 \times 850}{\mathbf{L D}_{\mathbf{5 0}}(\text { Oral })=771 \mathrm{mg} / \mathrm{kg}}
\end{aligned}
$$

\section{DISCUSSION}

The result of the phytochemical screening of the aqueous root bark extract of $S$. Iongipedunculata showed the presence of alkaloids, cardiac glycosides, flavonoids, saponins and tannins (Table 1). Saponins and tannins were found to be present in larger quantities than alkaloids, cardiac glycosides and flavonoids (Table 2). The reason may be due to the greater solubility of saponins and tannins in aqueous solution (Tailang and Sharma, 2009).

The presence of these chemical constituents in the aqueous root bark extract of $S$. longipedunculata is an indication that this plant if properly screened would yield drugs of plant origin with pharmacological significance. This is better supported by the fact that, the plant family (Polygalaceae) to which $S$. longipedunculata belongs, is known to be involved in ethnomedicine in the management of some ailments notably epilepsy (Mathias, 1982). They are also used as anti snake venom and as pugativ(Chhabra et al., 1991). In furtherance to this, the presence of alkaloids, cardiac glycosides, flavonoids, saponins and tannins in this plant is in compliance with an already documented literature which stated that, plant families (Polygalaceae), Moraceae, and Cannabinaceae are known to contain glycosides, triterpenes, resins and higher fatty acids in their stem and root bark (Evans, 1996). It is also important to note that, the plant species has varied biological activities when various solvents extract from its root bark were tested previously (Kamba and Hassan, 2010). This is clear indication that such biological activities are easily obtainable from this part of the plant, by considering the various chemical constituents that were detected. Thus the preliminary screening tests may be useful in the detection of the bioactive principles and subsequently may lead to the drug discovery and development. Furthermore, these tests facilitate the quantitative estimation and qualitative separation of pharmacologically active chemical compounds (Mallikharjuna et al., 2007).

Pharmacologically, a median lethal dose; $\mathrm{LD}_{50}$ (Oral) value of $771 \mathrm{mg} / \mathrm{kg}$ obtained is an indication that the

\section{REFERENCES}

Anonymous, (2007). Medicinal, Culinary and Aromatic Plants in the near EastMedic...http://www.faO.Org/dorep/x5402e16. htm (cited 4 August, 2007).

Atawodi, S.E., Bulus, T., Ibrahim, S., Ameh, D.A., Nok, A.J., Mamman, M. and Galadima, M. (2003). In vitro trypanocidal effect of methanolic extract of some Nigerian savanna plants. Afr. J. Biotechnol. 2(9): $317-321$. plant is slightly toxic to the experimental model (albino rats) used. This is in accordance with toxicity classification/scale of toxic substances (Hodge and Sterner, 2005).

It has been argued that even if $L_{50}$ values could be measured exactly and reproducibly, the knowledge of its precise numerical value would barely be of practical importance, because an extrapolation from the experimental animals to man is hardly possible (Lorke, 1983). However, it still serves a great purpose as a first pointer to the safety or toxic potential of a substance whose toxicity profile is not yet known (Kagbo and Ejebe, 2010).

The $\mathrm{LD}_{50}$ value of the root bark of $S$. longipedunculata was found to be lower than the $\mathrm{LD}_{50}$ (Oral) of Secuninega virosa; $5000 \mathrm{mg} / \mathrm{kg}$ (Magaji et al., 2008). This indicates higher toxicity of the root bark of $S$. longipedunculata compared to that of this plant.

\section{CONCLUSION}

The result obtained in this research, indicated the presence of all the phytochemicals tested in the aqueous root bark extract of $S$. longipedunculata. Saponins and tannins were found to be present in larger quantities than alkaloids, flavonoids and cardiac glycosides.

Acute toxicity evaluation of the extract classified it as slightly toxic to the experimental animals.

\section{Recommendations}

The root bark extract of this plant should be use in lower doses especially when use as a regimen for long term treatment of chronic illnesses in view of the possible toxicities that might result at high doses as indicated by the acute toxicity testing. It will be of great important to carry out sub-acute toxicity and histopathological evaluation of the different parts of this plant in order to assess its toxic effects on vital organs including liver, lungs and kidney. Further studies would be required to isolate the specific component(s) of the plant responsible for the toxicity in order to standardize the plant preparation for maximum therapeutic benefit.

Belmain, S.R., Neal, G.E., Ray, D.E. and Golob, P. (2001). Insecticidal and vertebral toxicity associated with ethnobotanicals used as post harvest protectants in Ghana. Food Chem. Toxicol. 39: 287-291.

Chhabra, S. C., Mahunnah, R. L. A. and Mshiu, E. N. (1991). Plants used in traditional medicine in eastern Tanzania. V. Angiosperms (Passifloraceae to Sapindaceae). J. Ethnopharmacol. 33: 143-157. 
Ciulei, I. (1994). Methodology for the Analysis of Vegetable Drugs. Chemical Industries Branch, Division of Industrial Operations, UNIDO, Romania; Pp. 24,26 and 67.

Cutler, J.C. (2010). Toxicity. In encyclopedia of earth. http://www.eoearth.org/article/toxicity. Retrieved August 2011.

El-Olemyl, M.M., Almuhtadi, F.J. and Afifi, A.A. (1994). Experimental phytochemistry: A laboratory manual. King Saud University Press, Saudi Arabia. ISBN 9960-05-05H3. Pp. 21-61.

Evans, C.W. (1996). Trease and Evans. Pharmacognosy, $14^{\text {th }}$ edition. W.B. Saunders company Itd., London. Pp. 268-270.

Harborne, J.B. (1973). Phytochemical Methods: $A$ Guide to Modern Techniques of plant Analysis. Chapman and Hall Ltd., London. P. 279.

Hodge and Sterner Scale. (2005). Toxicity Classes. In Canadian Centre for Occupational Health and Safety. Copy right (C) 1997-2010. http://www.ccohs.ca/oshanswers//d ${ }_{50}$. html 04/02/2010.

Kagbo, H.D. and Ejebe, D.E. (2010). Phytochemistry and preliminary toxicity studies of the methanol extract of the stem bark of Garcinia kola. Intern. J. toxicol. 7(2): 1-16.

Kamba, A.S. and Hassan, L.G. (2010). Anti-bacterial screening and brine shrimp (Artemia salina). Toxicity of Securidaca longipedunculata (Polygalaceae) root bark. Afr. J. Pharmaceut. Sci. Pharm. 1(1): 85-95.

Kaufman, P.B., Cseke, L.J., Warber, S., Duke, J.A. and Brielmann, H.L. (1999). Natural Products From plants. CRC Press, Boca-Raton, Florida. In: J. Med. Plnt. Res. 3(2): 86-95.

Lorke, D. (1983). A New Approach to practical acute Toxicity Testing. Arch. Toxicol. 53: 275 287.

Magaji, M.G., Anuka, J.A., Aguye, I.A., Yaro, A.H. and Hussaini I.M. (2008). Preliminary studies on anti-inflammatory and analgesic activities of Securinega virosa (Euphorbiaceae) in experimental animal model. J. Med. Plnt. Res. 2(2): 39-44.

Mallikharjuna, P.B., Rajanna, L., Seetharam, Y.N. and Sharanabasappa, G.K. (2007). Phytochemical studies of Strychnos potatorum I.f. amedicinal plant. E. J. Chem. 4(4): 510-518.

Mark, E.S. (1999). Toxicology for non - toxicologist. Governmment Institute, a division of ABS Group Inc. Rock ville, Maryland. http://www.eoearth.org/article/toxicology. Retrieved March 2011.

Mathias, M. E. (1982). Some medicinal plants of the Hehe tribe of the Southern highlands province, Tanzania. Taxon. 31: 488-494.

Maxwell, D.L.P., John, A.C., Noel, W.N., Steven, G.S. and Naanlep, T.M. (2007). The histopathological effects of Securidaca longipedunculata on heart, liver, kidney and lungs of rats. Afr. J. Biotechnol. 6(5): 591595.

Okigbo, R.N., Anuagasi, C.L. and Amadi, J.E. (2009). Advances in selected medicinal and aromatic plants indigenous to Africa. J. Med. Plnts. Res. 3(2): 86-95.

Okwu, D.E. (2004). Phytochemicals and vitamin content of indigenous spices of South Eastern Nigeria. J. Sustain. Agric. Environ. 6: 30-34.

Okwu, D.E.(2005). Phytochemicals, Vitamins and Mineral contents of two Nigeria Medicinal plants. Int. J. Mol. Med. Adv. Sci. 1(4): 375381.

Sofowora, A. (1993). Medicinal Plants and Traditional Medicines in Africa. $2^{\text {nd }}$ edition. Spectrum Books, Ibadan, Nigeria. P. 289.

Tailang, M. and Sharma, A.K. (2009). Phytochemistry; Theory and Practicals, $1^{\text {st }}$ edition. Birla publications pvt. Ltd., India. Pp. 15-39.

Tyler, V.E. (1999). Pyhtomedicines: back to the future. J. Nat. Prod. 62: 1589-1592.

Wannang, N.N., Wudil, A.M., Dapar, L.M.P. and Bichi, L.A. (2005). Evaluation of anti snake venom activity of the aqueous root extract of Securidaca longipedunculata in rats. $J$. Pharm. Bio. Res. 2(2): $80-83$. 